\title{
TRANSITION MECHANISM DEVELOPMENT TO THE SUSTAINABLE BALANCED DEVELOPMENT OF DEPRESSIVE TERRITORIES
}

Ugurchiev Omar Bashirovich 1, Dovtaev Said-Ali Shahidovich 2, Misakov Valery Safarbiyevich 3, Misakov Anzor Valerievich 4, Temmoeva Zariyat Ibragimova 5, Gyatov Anzor Vyacheslavovich 6

\begin{abstract}
1 Doctor of Economics, Professor, the Head of "Management" Department at FSBEI HE "Ingush State University"
2 Candidate of Economics, Associate Professor, Head of the Department "Enterprise Economics" at FSBEI HE

"Chechen State University"

3 Doctor of Economics, Professor of Institute of ecology of mountain territories of A.K. Tembotov of the Russian Academy of Sciences

4 Candidate of Economics, Senior Researcher, Department of "Innovation Process Economics" at the Institute of Informatics and Regional Administration Problems at FSBSC FSC "Kabardino-Balkarian Scientific Center of the Russian Academy of Sciences"

5 Candidate of Economics, Associate Professor of the Department "Economics and Management in Tourism" at FSBEI HE "Kabardino-Balkarian State University named after H.M. Berbekov»

6 Candidate of Economics, Associate Professor of the Department "State and Municipal Management" at FSBEI HE

"Kabardino-Balkarian State Agrarian University named after V.M. Kokov"
\end{abstract}

\begin{abstract}
The article considered the problems of territory withdrawal from a depressive state, various approaches are studied to the concept of "sustainable development". It was substantiated that it is expedient to consider economic growth as a determining indicator of development sustainability, showing the correlation between economic and other parameters of the system.
\end{abstract}

Keywords: transition mechanism, sustainable balanced development, depressive territories

\section{INTRODUCTION}

As a rule, the term "sustainable development" is used in economic theory to analyze and characterize such economic development that allows to ensure socio-ecological and economic security, to reproduce limited resources and distribute revenues fairly. The transition from quantitative to qualitative factors required a thorough study of sustainable economic development basic elements $[3,7,13]$.

\section{METHODOLOGY OF THE STUDY}

The subject of the study are the problems ensuring a stable and a balanced development of regional socio-ecological and economic systems. Various methods of economic research have been applied: comparative and logical analysis, functional and systemic approach, correlation regression analysis, and polyfactorial monitoring.

\section{STUDY RESULTS}

The genesis of approaches to assess sustainability and balanced development

The functional and economic justification of sustainable development strategy is based on the theory of flow maximization concerning the aggregate Hicks-Lindal income, which can also be created, if the aggregate capital is preserved at least through which this income is obtained. According to this concept, it is necessary to use limited resources and environmentally friendly energy and material-saving technologies optimally, from the extraction and the processing of raw materials to the destruction of consumption and processing waste.

Today, it is obvious that when you set the task of a balanced development it is necessary to proceed from the assumption that all three components of a sustainable development must be examined all together, taking into account the interaction of three concepts. For example, economic and social elements necessitate the solution of new tasks interacting with each other, in particular, the growth of life level and quality, the assistance to the poor, etc. taking into account the rights and the opportunities of future generations. 
The basis of a balanced development principle is the principles of optimization developed by F.Pareto [19]. They are even called "Pareto-optimization", which includes individual optimization, market efficiency and social optimum. Apparently, at this stage the ecological component was still absent.

Many modern researchers (V.I. Danilov-Danilyan, A.D. Ursul, V.A. Koptyuga and others) agree on a uniform understanding of sustainable development concept in general, defining it as ensuring a reasonable balance of society socio-economic development and environment preservation $[5,8,15]$.

The approach is interesting in which it is suggested that a sustainable development also has negative values of economic growth, caused by social and environmental constraints in addition to positive values of economic growth. Indeed, in principle, the difference between the concept of "sustainable economic growth" and the concept of "sustainable development" is the following one: in the course of economics functioning stability - for example, in the case of cyclical change amplitude, there may be a zero and even a negative value of economic growth, as compared to discrete growth.

It is advisable to consider economic growth in the form of development sustainability determining index, which shows the correlation between economic and other parameters of the system. Hence, sustainability is a universal property of various types of systems such as economic, technical, biological, including territorial ones.

The analysis and the generalization of different views on the essence of regional socio-ecological and economic system sustainable development allows to group all approaches into three blocks.

The supporters of the first approach offer to use the concept of "territorial system integral stability" from the position of existing subsystem balance, as well as the stability of economic indicator dynamics and the positive nature of structural shifts.

The supporters of the second approach propose to consider the sustainability of the regional economic system development from the position of security.

The supporters of the third approach propose to consider the level of achieved environmental safety as a fundamental criterion for sustainable regional development.

A sustainable development is a complex process that, in addition to the system of indicators, required the development of a special system of indicators in the UN, the World Bank, etc. There are also interesting developments of Russian scientists on this issue. In particular, the Academician M.Ch. Zalikhanov suggests special criteria and indicators as the indicators of sustainable development, through which it is possible to assess the level of a particular territory development (a region, a country, a continent), to forecast its perspective position taking into account socio-ecological-economic, political, demographic and other factors, and also to formulate the conclusions about the stability of an existing state [6].

Professor S.N. Bobylev notes the need to take into account the developed indicators of economic, social and environmental aspects of meeting the needs of the present generation without harming the needs of future generations [7].

In any case, it is obvious that at the development of a sustainable balanced development concept of regional economic systems it is impossible to do so without the following triad: society-economynature. This, naturally, makes to consider all occurring social, ecological and economic processes as a single whole $[1,10,17]$.

\section{The peculiarities of state social and economic policy transformation in the regions}

The ongoing transformation of state social and economic policy in the regions is caused by the need to change the vector of its goal-setting. Judging by the support that is performed by the state it is impossible to assert that the regional economic policy is aimed at the development of the territories, because it does not allow us to bring the regions to the trajectory of sustainable development. All this forces the regions (in addition to state support) to develop the priority directions for the creation and the implementation of their own territorial development policies based on the search for internal reserves, 
on own resource balance optimization (first of all, these are endogenous factors - natural and climatic, material, labor and financial-economic resources, etc.) and the transfers in the form of federal targeted programs.

Speaking about the economic space of Russian Federation, it is probably not entirely correct to call it a unified one, in view of the extreme differentiation of its territories by center-periphery type with respect to economic development. At that, this inequality only grows annually, which has already led to socioeconomic degradation of the country isolated regions. The economic inequality of the subjects has reached such a point that it should be viewed as an independent factor restraining the growth of the gross regional product, etc. In addition, the center needs to understand that this situation has a negative impact on the country economic growth. It seems to us that state structures do not feel the trend of economic destructiveness yet, otherwise there would be an effective state policy to ensure economically homogeneous development of all regions of the country. The experience of Western countries and theoretical developments show that at a twofold gap in the values of the main indicators (GRP per capita, average wages, etc.), the situation in depressed areas is a critical one. We have the same circumstances in Russian Federation, when the income gap in the regions exceeded 100 points, and therefore, we need to abandon the universal approach to all the regions of Russian Federation urgently. The government, apparently, believes that the territorial security of the country is ensured only by the performance of an artificial mass subsidization of Russian Federation. Obviously, we need real tools that ensure a selective economic approach to the territories, and the use of which will allow us to overcome a depressive state and to catch up with the leaders in the future. The state support in all the republics of the North Caucasus, except of the Chechen Republic, is so meager that the republics are doomed to be depressed. Moreover, taking into account the depressiveness in the republics, the lack of coordinated management by a balanced development of the territories is especially acute [4, 11, 12].

The basis for the crisis consequences of the economy removal in the depressed republics of the NCFD, its transition to sustainable social and economic development can be the development of balanced regional development concept. It should rely, first of all, on the self-development of the depressed republics, on the one hand, and an optimal influence on the national policy of the central authorities at the implementation of joint projects. Hence, it is quite appropriate to understand a balanced development of a regional economic system as the development which takes place through an effective use of regional factors, while providing a continuous support to the conditions for the dynamic reproduction of a region potential. The reality of an effective support for the conditions of dynamic reproduction can be established by the number of profitably operating economic entities of the territory among their total number. Naturally, the higher the percentage of profitably operating economic organizations, the more effectively the regional economic system operates $[9,14,16,18]$.

It is believed that the number of profitable enterprises of a regional economic facility should be at least $80 \%$ to consider that the regional economic system is at the stage of a balanced development. For comparison, this indicator does not reach 50\% in the depressed republics of the North Caucasus.

The next indicator characterizing the balance of regional policy is the share of small businesses in the gross regional product.

It is less than $10 \%$ in the republics of the NCFD, whereas, for example, in such countries as Germany, France, Austria it makes $60 \%$ at least.

Speaking about the balanced development of the regional economy in the republics of the North Caucasus Federal District, it is necessary first of all to take into account the genetic features of the socio-economic development of the territories, the mentality, the underestimation of environmental problems, the raw orientation of the regional economic facility, its structural deformation, the primitivism of GRP structure and the lack of real prerequisites for innovative activities, etc.

In the conditions of increasing competition for regional economic facilities, it is especially difficult to maintain the conditions for the reproduction of the territorial potential in a balanced development mode with a social orientation. It is unequivocal that the development of the territory can not be carried out 
within the framework of a strictly linear form, for this process is always accompanied by recessions and ups and the periods of accumulation and utilization of the accumulated development resources.

The parameters of sustainable development (we consider this as a positive vector dynamics) can be expressed in the form of adequate long-term dynamic series of forecast and real characteristics of the regional economic system. A competent, i.e. scientifically grounded establishment of "growth points" of the regional economic system and the priority areas of balanced development of territories allows us to concentrate material, financial, economic, labor and other reserves to implement the key areas of sustainable development of the region economic system.

It is indisputable that in any case depressive agrarian-oriented republics of the North Caucasus can not do without a multi-level support, which requires the harmonious integration of self-development mechanisms of the regional economic system into the social and economic policies of both federal and subfederal state structures. This is confirmed by the world experience of developed countries, in which territorial alignment has always been carried out through direct regulation of land, state development, etc. by a state. Moreover, if serious public investments are really needed during the first period, then a reasonable state policy of the organizational and legal interaction system for territorial regulation becomes more necessary.

We are far from claiming that it is easy to regulate the conflicts of interests, in particular, between production workers and environmentalists, etc., which makes it necessary to approach the regulation of all regional development processes in a very careful way and consider all this in the form of an organized set of interconnected regulatory measures in socio-ecological and economic sphere. Moreover, it seems to us that only such an approach can become a necessary condition for a balanced and a socially-oriented development of the regions.

Of course, it is incorrect to compare the economy of the depressed republics of the NCFD, for example, with the economy of the Republic of Tatarstan: historically, the North Caucasian republics were considered and developed, primarily as health resorts, which did not require special investments in those years while the oil-producing, petrochemical and other industries developed quite rapidly in Tatarstan (due to oil availability).

\section{Exclusive reserves of the depressed republics of the North Caucasus}

At the same time, there are special reserves and resources in the republics of the North Caucasus, which can be used effectively if desired, on the basis of which it is possible to form the conditions for the transition of these RF subject economy for a sustainable development on the principles of balance and self-sufficiency. In addition to tourism and recreation, such resources can be the agrarian sector, where it is possible to produce ecologically clean products in large quantities (meat, milk, etc.), although, of course, this industry is still unprofitable nowadays.

Undoubtedly, there are large reserves when the shadow economy is brought to a legal position. Experts estimate that the volume of shadow incomes of the North Caucasian republics population varies within the limits of 8-10 billion rubles, which has a very negative impact on the regional budget. With a skillful management, these funds can be channeled to the economy of the regions, which will increase the region budget by $30-35 \%$.

It should be noted that the talks about such measures are held at all levels for many years. It is necessary to launch an effective mechanism in the shortest possible time, which will allow the regional economy to move to a stable state. It seems to us that 5-7 years are enough for this. Otherwise, the republics of the North Caucasus will remain subsidized for decades, with a permanent significant deficit of the regional budget.

All of the foregoing confirms objectively the need for economy transition period of the depressed NCFD republics on a balanced development track. At the same time, it is necessary to solve rather complicated and significant problems characteristic of the economy of these regions, also to transform

Submit Date: 10.01.2018, Acceptance Date: 23.02.2018, DOI NO: 10.7456/1080MSE/131

Research Article - This article was checked by Turnitin

Copyright (C) The Turkish Online Journal of Design, Art and Communication 
the deformed structure of the economy, to replace equipment at the enterprises of the basic industries (the wear of which makes no less than $80 \%$ ), to eliminate technological backwardness and to neutralize an unacceptably high degree of production monopolization in the regional economy of individual territories of the North Caucasus Federal District. The processes of a territory regional economy transfer involve the use of such principles as stability and the economy balance, the improvement of the republic population life quality, the establishment of growth points in the regional economy, and others. Unambiguously, profitable enterprises should be the main source of the regional economic system balanced development. Besides, additional sources may be represented by such areas as the sale of products of the main sectors of regional economy at fair prices, the departure from the policy of unilateral growth of prices and tariffs, the refusal from the shadow economy, and the increase of financing volumes from the federal programs to the social and environmental spheres of a region.

It is also clear that without the innovation stimulation, it is impossible to overcome the depression of the republics. In order to activate this direction, a serious state support of priority projects is required through the formation of innovative centers, the modernization of production, the use of advanced technologies, the creation of a new information infrastructure of research institutes, etc.

All abovementioned features of the transition period of the economy on the way of balanced development, as well as the identified principles and sources of its implementation can be viewed as the integral elements of balanced development concept for regional socio-ecological and economic systems of NCFD republics, which requires the creation of a mechanism for a regional economic system development, taking into account the principles of a stable and a balanced functioning.

\section{The mechanism of transition to sustainable balanced development of the regional socio-ecological and economic system}

The theoretical and methodological provisions of active system theory can be an effective tool for such an analysis, since its components have the right to make the necessary decisions and select the vector of their development, taking into account the impact of factors of the internal and the external environment.

The underlying theory of active systems is the so-called developing active system, in which active as well as self-developing elements act as a control object.

The transition mechanism is formed on the group of principles necessary for the existence of developing active systems, including such as the denial of a spontaneous self-development of developing active elements, interconnectedness and interdependence of subsystem center measures, sustainability and the allocation of balance growth points. In our case, the mechanism for the transition of the regional economic system to a balanced development should be considered in the form of a formal description, analysis, diagnosis and the synthesis of an actively developing system mechanism activity, taking into account the impact of external and internal factors. Hence, the regional economy appears as a multi-level hierarchical So system, which is a self-developing element of the regional economic system and, moreover, acting as a large hierarchical So. The structure of this regional system includes such elements as the center (regional authorities), as well as the subsystems subordinated to it.

Hence, the mechanism of transition to a sustainable balanced development of the regional socioecological and economic system is expedient to consider as the combination of methods of data generation, information base, the algorithm of management procedures, the motivation and stimulation complex...

\section{CONCLUSIONS}

The development of a territory can not be carried out within the framework of a strictly linear form, for this process is always accompanied by declines and ups and the periods of the accumulated development resource accumulation and utilization. The achievement of a balance within the framework of state social and economic policy should be ensured through a consistent implementation of comprehensive measures for the determination and elimination of an economic asymmetry between regions, as well as by the development of a target program to ensure the economically homogeneous development of Russian Federation subjects. The results of the study can be used by regional authorities 
during the development of preventive measures to localize and neutralize the problem areas at a local level. Such an approach allows to form an effective operational management on the ground.

\section{Conflict of interest}

The authors confirm that the presented data do not contain a conflict of interest.

\section{REFERENCES}

Aaker J. Marketing research. 7th edition, trans. from English. - St. Petersburg: Peter, 2004. - 848 p. Adzhieva A.Yu., Misakov A.V., Dikareva I.A. Audit risk in the planning of financial result audits. From the collection: Modern economy: current issues, achievements and innovations. The collection of articles by the winners of the IIIrd International Scientific and Practical Conference. 2016. pp. 74-77. Bekova O.O., Ozdoeva D.M., Misakov V.S. Integration as the basis for a regional production facility development. Economic sciences. 2011. № 85. pp. 163-167.

Gauzhaev A.Z., Mairov A.Yu., Misakov V.S. Institutional and organizational context of the modernization strategy for the development of regional production facilities. Terra Economicus. 2013. Vol. 11. № 2-2. pp. 62-66.

Danilov-Danilyan V.I. Ecologization of the national economy as the basis of sustainable development // Ecology. Economy. Business. - Moscow: Iris Press, 1995.

Zalikhanov S.L. Scientific basis of RF sustainable development strategy // Report at the conference in Johannesburg. - 2002.

The indicators of sustainable development in Russia (ecological and economic aspects) / ed. by Bobylev S.N., Makeev P.A. / - M.: CPRP, 2001.

Koptyug V.A. The main factors that cause the need for the transition of mankind to a sustainable development // The materials of the scientific conference "Reforms in Russia from the standpoint of sustainable development concept." - Novosibirsk: "The Civil World", 1995.

Misakov VS Methodological bases of modeling of process of the economic analysis of a condition of business. Kabardino-Balkarian Science Center of the Russian Academy of Sciences, Institute of Informatics and Problems of Regional Management. Nalchik, 2006.

Misakov V.S. Theory and practice of a firm competitiveness analysis. Nalchik, 1996.

Misakov V.S., Kuyantsev I.A., Kazancheva Kh.K., Dikinov A.Kh., Kilchukova A.L., Efendieva A.A., Sabanchiev A.Kh., Misakov A.V., Abaev R.M. The prediction and the assessment of the opportunities for a sustainable development of problem regions. Scientific editor V.S. Misakov. Nalchik, 2015.

Misakov V.S., Cherkesov S.Kh. Socio-economic consequences of shadow relations corruption in regional economy. The news of the Kabardino-Balkarian Scientific Center of the Russian Academy of Sciences. 2013. No. 6-2 (56). pp. 176-181.

Misakov V.S. The problems of socio-ecological and economic security provision in the mountain areas of the South of Russia. Bulletin of the Kabardino-Balkarian Scientific Center of the Russian Academy of Sciences. 2016. No. 1 (69). pp. 113-120.

Totorkulov Sh.M., Etlukhov O.A.G., Misakov V.S. The actual problems of small business development in modern conditions. The issues of economics and law. 2011. № 42. pp. 123-127.

Ursul A.D. Russia transition to sustainable development. Noosphere strategy. -M.: Noosphere, 1988.

Shevlokov V.Z., Ashibokov B.A., Misakov V.S. Leasing as the form of investment in the agricultural sector of economy. Economic sciences. 2011. № 85. pp. 182-185.

Shevlokov V.Z., Misakov V.S. The guidelines for investment and business climate improvement in the CBR. Bulletin of the Kabardino-Balkarian Scientific Center of the Russian Academy of Sciences. 2014. No. 2 (58). pp. 110-113.

Misakov V.S., Kuyantsev A.I., Dikinov A.H., Kazancheva H.K., Misakov A.V. National agriculture modernization on the basis of import substitution. International Business Management. 2016. T. 10. № 10. C. 1946-1951

Pareto V.F. Manual of Political Econom. - London, 1906 